\title{
RECOMMENDED ELEMENTS OF INFOGRAPHICS in Education (Programming Focused)
}

\author{
Husni Naparin and Aslina Saad \\ Universiti Pendidikan Sultan Idris, Tanjung Malim, Perak, Malaysia
}

\begin{abstract}
This study focused on investigating the elements of infographics in the field of education especially in Programming. It was done by reviewing related literature reviews, interviewing experts in design, content, and the current infographics in programming. The findings showed that based on literature review a good infographic should consist of a good title, suitable graphs/charts/pictures/images, readable text/font, a clear story, reliable data, have an excellent use of color and an appropriate design format. Based on six design experts stated that the position, location, and identification of each element in infographics design to make it clear to the audience. Furthermore, content expert explained some important points of data structure and algorithms. The last one is taken from 6 current infographics which contained 7 elements. This is important to enhance the reader's understanding of the content of the infographic because it should present information in a clear, concise, and effective manner.
\end{abstract}

\section{KEYWORDS}

Infographics, Infographics Elements, Education

\section{INTRODUCTION}

There are a lot of infographics that have been used in different areas such as business, health, industry, advertisements, e-commerce and education. The design of an infographic needs to be suitable with its aim. For example, in business, an infographic is used to promote a service or a product or as a marketing strategy. On the other hand, in the field of education, an infographic can be used as a kind of instructional media and is aimed to increase students' understanding of the subject's content. Therefore, the design of infographic for educational purposes is very important to be investigated. There are several elements that have been identified. This study aimed to choose the appropriate elements for educational infographics particularly in the subject of programming.

This research is really urged to do because there are several difficulties arise during the learning process of basic programming concepts such as program construction [1], loops manipulation [2], structures control and algorithms [3]. In addition, [4] stated that computer programming learning is a difficult process. They demonstrated that many students find difficult to use programming languages to write programs to solve problems and do not know how to create algorithms. Many novice students even show difficulties to use basic concepts like control structures to create algorithms that solve concrete problems.Data structure and algorithms are very important elements in computer science and education field because they influence memory faults and make the speed of memory slower if students do not understand the implementation of those algorithms in operating computer programming, These materials are very useful to make the program running well [5]. 
The International Journal of Multimedia \& Its Applications (IJMA) Vol.10, No.6, December 2018

\section{METHODOLOGY}

The methodology of this study involved 4 phases which were: reviewing literature, interviewing six experts of infographics design about their opinion of infographics elements for programming and also an expert about the content of data structure and algorithms, and then searching for current infographics related to programming whose design were in line with the literature review and the experts' statements. Table 1 shows the 4 phases of this study.

Table 1. Description of methodology

\begin{tabular}{|c|c|c|c|}
\hline $\begin{array}{c}\text { Sources of } \\
\text { Data }\end{array}$ & $\begin{array}{l}\text { Techniques of data } \\
\text { collection }\end{array}$ & Data Analysis & Objectives \\
\hline review & $\begin{array}{c}\text { Searching for reliable } \\
\text { sources from 18 } \\
\text { articles from various } \\
\text { journals }\end{array}$ & $\begin{array}{c}\text { summarizing and } \\
\text { synthesizing the elements of } \\
\text { infographics and writing } \\
\text { them become reliable } \\
\text { information }\end{array}$ & $\begin{array}{c}\text { To make justification } \\
\text { and judgement about } \\
7 \text { infographics } \\
\text { elements in education }\end{array}$ \\
\hline $\begin{array}{c}\text { Experts of } \\
\text { Design }\end{array}$ & $\begin{array}{c}\text { Interviewing six } \\
\text { experts about their } \\
\text { opinions on } \\
\text { infographic elements }\end{array}$ & $\begin{array}{c}\text { Considering their opinions, } \\
\text { experiences and expertise in } \\
\text { making the conclusion of } \\
\text { infographic elements for } \\
\text { education. }\end{array}$ & $\begin{array}{c}\text { To ensure that } \\
\text { experts have already } \\
\text { known and used } \\
\text { those elements in } \\
\text { their designs }\end{array}$ \\
\hline $\begin{array}{c}\text { Expert of } \\
\text { Content }\end{array}$ & $\begin{array}{c}\text { Interviewing the expert } \\
\text { of data structure and } \\
\text { algorithm }\end{array}$ & $\begin{array}{c}\text { Analyzing the content of the } \\
\text { materials for inclusion in the } \\
\text { infographics }\end{array}$ & $\begin{array}{c}\text { To know the best way } \\
\text { to teach data structure } \\
\text { and algorithm }\end{array}$ \\
\hline $\begin{array}{c}\text { Current } \\
\text { infographics }\end{array}$ & $\begin{array}{c}\text { Selecting 6 } \\
\text { infographics focused } \\
\text { on programming }\end{array}$ & $\begin{array}{c}\text { Collecting the information of } \\
\text { the position, location, and } \\
\text { identification of each } \\
\text { element in these existing } \\
\text { infographics }\end{array}$ & $\begin{array}{c}\text { To examine these } \\
\text { current infographics } \\
\text { in light of the } \\
\text { literature review and } \\
\text { experts opinions }\end{array}$ \\
\hline
\end{tabular}

\section{RECOMENDED ELEMENTS FOR INFOGRAPHICS IN EDUCATION}

\subsection{INFOGRAPHICS DESIGN AND ELEMENTS BASED ON A REVIEW OF THE LITERATURE}

This literature review was based on technical relevancy that highlights the overall description of the research area related to the infographics design in education especially in programming. The guidelines found here have been categorized into seven elements of infographics.

\subsubsection{Title}

A title is the most important aspect in any material such as a book, blog, etc which reflects the content being presented. The same applies to titles in infographics. [6] reported that a title should grab a reader in seconds to read infographics and should have a persuasive headline which is responsible for $90 \%$ of people viewing (or not viewing) an infographics.

\subsubsection{GRAPHS/CHARTS/PICTURE/IMAGES}

There are different kinds of graphics that can be found in infographic content such as graphs, charts, pictures, and images. According to [7] different types of diagrams such as tree diagrams, network diagrams, statistical diagrams, schematic diagrams, or concept diagrams can be used. In 
The International Journal of Multimedia \& Its Applications (IJMA) Vol.10, No.6, December 2018 addition to this, [8] stated that in infographic design, the icons, statistics, references and facts can also be found. For the meaningful representation of data there can be maps (flow maps, mind maps), charts (pie charts or line charts) that are often used for displaying data values, and graphs (a bar graph or a stacked bar graph) to give a maximum effect of the infographic and it is called the Picture Superiority Effect [9]. On the other hand, line strokes are used with various widths and colors to help encode information and picture symbols should be consistent and so familiar [10].

\subsubsection{TEXT/FONT}

Text often takes the form of labels and can give short explanations to make the data more useful. [11] affirms that linear text can be used where ideas, concepts and connections are visibly highlighted by graphic devices such as diagrams, charts and maps. In addition, [12]asserts that simple text messages combined with a relevant image, simple graphic configuration, or chart can make a lasting, memorable, impression on the audience to be more actively involved and engaged in higher message elaboration and to support the comparison of relative levels of information.

\subsubsection{STORY}

The story of an infographic usually includes a mark, a symbol or visual element typically stands for quantitative information to effectively and efficiency present information, while color, size and shape usually describes the qualitative aspect by [13]. According to [14] the story should elucidate complex concepts in a user-friendly manner to a desired audience.

In the research of [15] the infographic story is designed to communicate a specific set of information to a certain audience by turning complex and abstract concepts into intuitive knowledge, illustrate data and textual information using icons, images, colors and elements of graphic design. Furthermore, [16] states that the information flow/process which infographics contain shows some sort of flow or process in which the individual data points fit into an overall context. Another opinion from [17] states that design can be divided into several elements of space provided as the regulation of story.

\subsubsection{DATA}

[18] professes that to communicate clearly, the context needs to be provided for an infographic. According to [19] in making the data for an infographic, one needs to do research and limit sources and avoid using contradictory materials. Preferably, one should not use data older than a year and up to a maximum of two years (one should always list the timeframe of data relating to the graphic). Besides, [20] states collecting and processing data include the raw data and a series of actions makes a good visualization for infographics.

\subsubsection{Colour}

According to [21], colorfulness is the integration of specific colors with saturation and a number of image areas in a given image. Colorfulness is also used for perceptual models and complexity as an estimate for visual appeal in determining the colors. In addition, [22] thought that color schemes are better if there has been some consideration for people who are color blind. Furthermore, getting the color balance and relevance right is not an easy task but is very important for infographic design as stated by [23]. Based on [24] study that a choropleth map can 
The International Journal of Multimedia \& Its Applications (IJMA) Vol.10, No.6, December 2018 be used as the dominant visual representation for color design and it has been recommended that a spectral color sequence from yellow to red be followed with the lighter more luminous yellow indicating less and the darker less luminous red indicating "more", and a neutral grey be used for which data is missing.

\subsubsection{Design ( Format, Quality, Performance And Aesthetics)}

Research by [25] reports that illustration is a unique and impactful visualization can be applied to individual visual elements in infographics as a part of design. [26] explains the use of elements like spacing and dividing lines to distinguish the content sections from one another. According to [27] vertical infographics are also easier to view on most browsers and mobile devices, and tend to get much more social media shares compared to horizontal infographics. Then there is the issue of the size, the height and width, the height/width ratio and the black pixel density of each connected component constructed for an infographic. The connected components are classified into three types: graphical components, textual components and noise.

There are four categories of infographic design (bullet list equivalents, snapshots with graphic needs, flat information with graphic needs, and the information flow process [28]. The concept of design can be adapted into several criteria including visual aspects, verbal messages, and media specifications for infographics [29]. Hyperlinks are also commonly used in infographics as a means to engage news readers in news acquisition [30]. Table 2 is highlighting description of each infographics element and the importance of elements combination from different literature review for standardization infographics elements in education.

Table 2. The Importance of infographics elements based on literature review

\begin{tabular}{|c|c|c|c|}
\hline NO & $\begin{array}{l}\text { INFOGRAPHICS } \\
\text { ELEMENTS }\end{array}$ & $\begin{array}{l}\text { LITERATURE } \\
\text { REVIEW }\end{array}$ & $\begin{array}{l}\text { IMPORTANCE OF INFOGRAPHICS } \\
\text { ELEMENTS }\end{array}$ \\
\hline 1 & Title & Dalton (2014) & $\begin{array}{l}\text { Responsible for } 90 \% \text { of people viewing (or not } \\
\text { viewing) an infographics. }\end{array}$ \\
\hline \multirow{3}{*}{2} & \multirow{3}{*}{$\begin{array}{l}\text { Graphs/Charts/ } \\
\text { Picture/Images }\end{array}$} & Marabella (2014) & $\begin{array}{l}\text { To represent meaningful data and to display data } \\
\text { values }\end{array}$ \\
\hline & & Zhao (2015) & Give a maximum effect of the infographic \\
\hline & & $\begin{array}{l}\text { Handaru, et al., } \\
(2015)\end{array}$ & $\begin{array}{l}\text { Help encode information to be consistent and } \\
\text { familiar }\end{array}$ \\
\hline \multirow[b]{2}{*}{3} & \multirow[b]{2}{*}{ Text/Font } & Yani, et al., (2015) & Give short explanations to make data more useful \\
\hline & & Krum (2014) & $\begin{array}{l}\text { Make a lasting, memorable, impression on the } \\
\text { audience to be more actively involved and engaged } \\
\text { in higher message elaboration and to support the } \\
\text { comparison of relative levels of information. }\end{array}$ \\
\hline \multirow[b]{2}{*}{4} & \multirow[b]{2}{*}{ Story } & Smiciklas (2012) & $\begin{array}{l}\text { Elucidate complex concepts in a user-friendly } \\
\text { manner to a desired audience }\end{array}$ \\
\hline & & Lyra, et al., (2016) & $\begin{array}{l}\text { To communicate a specific set of information to a } \\
\text { certain audience by turning complex and abstract } \\
\text { concepts into intuitive knowledge, illustrate data } \\
\text { and textual information }\end{array}$ \\
\hline \multirow{3}{*}{5} & \multirow{3}{*}{ Data } & Krum (2014) & To communicate clearly \\
\hline & & Dalton (2014) & $\begin{array}{l}\text { To limit sources and to avoid contradictory } \\
\text { materials }\end{array}$ \\
\hline & & Yani, et al., (2015) & To give and 1 \\
\hline
\end{tabular}


The International Journal of Multimedia \& Its Applications (IJMA) Vol.10, No.6, December 2018

\begin{tabular}{|c|c|l|l|} 
& & & information will be delivered \\
\hline \multirow{4}{*}{6} & \multirow{2}{*}{ Colour } & $\begin{array}{l}\text { Harrison, et al., } \\
(2015)\end{array}$ & $\begin{array}{l}\text { For perceptual models and complexity as an } \\
\text { estimate for visual appeal }\end{array}$ \\
\cline { 3 - 4 } & Zhao (2015) & For making consideration of color blind people \\
\cline { 3 - 4 } 7 & $\begin{array}{c}\text { Dalton (2014) } \\
\begin{array}{c}\text { Design ( Format, } \\
\text { aulity, Performance } \\
\text { and Aesthetics) }\end{array}\end{array}$ & Marabella (2014) & $\begin{array}{l}\text { For getting the color balance and relevance right } \\
\text { another }\end{array}$ \\
\cline { 3 - 4 } & Lee \& Kim (2016) & $\begin{array}{l}\text { As a means to engage news readers in news } \\
\text { acquisition }\end{array}$ \\
\hline
\end{tabular}

\subsection{INFOGRAPHICS DESIGN AND ELEMENTS ACCORDING TO DESIGN EXPERTS}

In designing a good infographics, 7 elements should be included based on this literature review and six (6) experts in design discuss these elements below. Expert 1, 2, 3 are from Indonesia. While expert 4, 5, 6 are from Malaysia. The experts from Indonesia are online course facilitators which use infographics as their media and having experience in designing infographics for years. In addition, the experts from Malaysia are infographics designers in university for more than five years and their masters focused on design.

The title element should be in the top-centre; font size is bigger and depends on the information be delivered [31], [32], [33], and [34]. The position should be on the top and depends on the size of paper for example A4 and uses formal font [35]. On the other hand, the font should be different from the font used for the content [36]. Alternatively, the title should be short and did not recommend long title [37]. Add spaces and should be read easily, interesting results and appropriate with a new era of design [38]. The last is title position should be easily seen, readable, clear, eye-catching, and use an appropriate color[39].

Graphs/charts/pictures/images according to experts have various judgements. For instance, adding diagrams, pie charts, or icons, with a data proportion of $50 \%$, making a mind map and adding pictures/ images [40]. On the other hand, it depends on the formality of presenting the information [41] while focused on the layout starting from the top and with the diagram's position on the side/centre[42]. In addition, related to the title / topic, contents describe as soon simple [43] and[44]. The last thing, related to creativity and a creator can use an illustration, tracing, or vector. The position also can be on the right or the left and might use an effect from Photoshop [45].

Text/font should use informal but readable fonts and depends on the topic[46] and [47]. One should use simple text and not be too long [48], one should simply use points, create icons by using creative and interesting vectors [49]. On the other hand, using two types of fonts, neither small nor too big and should be tidy [50]. Similarly, one should use important points with a maximum of two sentences[51]. While, using types of any formal texts, clear content, and make it as simple as possible [52]. San Serif fonts (plain text) are the mostly used font for infographics. In the same way, write concisely to make the graphic flow and easy to read for the readers [53]. Fonts should be clear and contrast, not many sentences should be used, with suitable space and appropriate margins and paper space left or top for explanations [54].

Data should make use of diagrams, pie charts, or icons to help the visualization of the data so that readers can easily grab information [55]. Another way to make data clear by writing certain points on a piece of paper, to get a better idea of what to put in infographic, and consider how many points to present ([56]. On the other hand, made an infographic about teaching and learning 
The International Journal of Multimedia \& Its Applications (IJMA) Vol.10, No.6, December 2018

includes general explanation about topic, subtopic, and decide for mapping location of data in the infographic [57]. Data is an essential part of an infographic because without data there are only 'graphics' and no 'info', the presentation of texts, the need for pictures to be clearly understandable, user friendly and for the location be in the centre, with a logo placed in the top centre, left, or right [58]. Additionally, content, text, and an explanation can be used to present data in an infographic [59]. Creativity, thinking that vector or tracing objects, composition and location should be set creatively in the graphics layout [60].

Story: different elements should relate to one another by adding pictures/ images to strengthen the information[61] and[62]. One needs to understand students' level and characteristics to make a suitable design for their audience based on a certain topic[63]. On the other hand, a designer highlight a topic, then present other information [64]. Text and images to be displayed are related to each other, tracing and illustration should be suitable with topics and patterns by combining title of a new era of design[65]. Designers should pay attention to topic first, related concepts, suitable images, and make their audience interested [66].

Clarifying about colours, it is good to use soft colours for the background, brighter colours for text, so that the topic can be read easily. Typically, size is connected with space, shape is related to colours and texts have a close relationship with colours and the choice of suitable fonts [67]. The best color is a combination of white and black [68], uses basic colours such as red, yellow, green, and blue [69]. Use bright colors and that the background should be contrasted with the fonts used for the content [70] and [71]. Data or highlight should have brighter colours but the rests should not be too dark, the colours should be appropriate with topics and include the newest trends of a new era of design [72]. Similarly, there should be a match if there is a combination of two colours[73].

The last is design, both landscape and portait could be usedas long as the elements were connected each other. To make an infographic clear, the title should be in the form of a circle placed in the centre and information should be well-summarized and arranged visually[74]. While have lining, mapping based on creativity, informative data and experience to compare with others to enrich the ability of designing [75].Further, everything should be integrated into one topic or theme appropriate for students 'level and characteristics, the designer should highlight the topic, then present other information by giving a simple explanation (catchy) and it should be easy to understand [76]. Designers should add meaningful images, decorate with visual objects by giving some sparks and put together a few design elements to form a visual interesting story [77]. Alternatively, zigzags, left to right, or top to bottom and continuing to the right, left to right and continue to right to left in the form of circle [78].On the other hand, picture size larger consider about space, colors should allow for clear shape and text, including all important elements for the sake of creativity, design interest and sense based on a new era of design [79].

\subsection{CONTENT EXPERT FOR INFOGRAPHICS MATERIALS}

The third step for this research project was analyzing content about programming. Data structure and algorithm topics were chosen to explain principles of basic programming and explain each subtopic about data structure and algorithm. An expert in teaching data structure and algorithms are from Malaysia. She explained some important points to deliver in the content of a potential infographic. 
The International Journal of Multimedia \& Its Applications (IJMA) Vol.10, No.6, December 2018

Data structure is the way to arrange data which is used in every application or data institution or data structure including stacks, trees, arrays, queues, linked lists, and graphs. Algorithms consist of pseudo code and a flowchart. The problem that needs to be solved is the challenges in teaching data structure and algorithm because it is difficult to know how to select appropriate data structure in every case. Moreover, in teaching data structure and algorithms, lecturers have to include real world application analogies in every subtopic in order for students to understand. An analogy is the best technique for explaining every subtopic and to understand the main concepts of data structure and algorithms are based on the types needed. The most important topic is arrays and linked lists, because those topics are indispensable, because they connected with other subtopics while the most difficult topic is linked list and graph. The first subtopics that must be explained is arrays and linked lists because they are related with basic concepts in programming. The last instruction is creating full operations of each data structure for example insert, remove, search, etc[80]

\subsection{INFOGRAPHICS DESIGN AND ITS ELEMENTS FROM CURRENT INFOGRAPHICS}

The last phase of this study was choosing infographics based on the criteria uncovered in the literature review, design experts and programming expert. 6 current infographics are analysed in light of the literature review and experts' statement. Table 3 is a summary and explanation of the 6 infographics which fulfilled the requirements to be considered in the category of good infographics in the field of education because they contained the important elements of infographics design: title, graphs/charts/pictures/images, text/font, story, data, color, and design (format, quality, performance, and aesthetics).

Table 3. The Description of Elements of 6 Current Infographics

\begin{tabular}{|c|c|c|c|c|c|c|c|}
\hline Title & $\begin{array}{c}\text { Title } \\
\text { Positio } \\
\text { n }\end{array}$ & $\begin{array}{c}\text { Graphs, } \\
\text { Charts, } \\
\text { Pictures, } \\
\text { and } \\
\text { Images }\end{array}$ & $\begin{array}{l}\text { Types } \\
\text { of } \\
\text { Texts/ } \\
\text { Fonts }\end{array}$ & $\begin{array}{l}\text { Introduction, } \\
\text { definition, } \\
\text { conclusion, } \\
\text { Sources }\end{array}$ & $\begin{array}{l}\text { Types of } \\
\text { data used }\end{array}$ & $\begin{array}{l}\text { Colours } \\
\text { used }\end{array}$ & $\begin{array}{l}\text { format, } \\
\text { quality, } \\
\text { perform } \\
\text { ance, } \\
\text { aesthetic } \\
\text { s } \\
\text { (number } \\
\text { s, } \\
\text { shapes, } \\
\text { and } \\
\text { symbols) }\end{array}$ \\
\hline $\begin{array}{l}\text { An } \\
\text { overview } \\
\text { of } \\
\text { computer } \\
\text { programm } \\
\text { ing }\end{array}$ & Left & $\begin{array}{l}\text { Pictures, } \\
\text { charts }\end{array}$ & $\begin{array}{l}\text { Linear } \\
\text { text in } \\
\text { the box }\end{array}$ & $\begin{array}{l}\text { Introduction, } \\
\text { sources }\end{array}$ & $\begin{array}{c}\text { Definition } \\
\text { and history of } \\
\text { programming } \\
\text { languages, } \\
\text { and diagrams }\end{array}$ & $\begin{array}{l}\text { White, } \\
\text { black, } \\
\text { orange, } \\
\text { grey, and } \\
\text { purple }\end{array}$ & $\begin{array}{c}\text { use of } \\
\text { symbols }\end{array}$ \\
\hline $\begin{array}{l}\text { Why } \\
\text { JavaScript } \\
\text { is the } \\
\text { future of } \\
\text { programm } \\
\text { ing? }\end{array}$ & Centre & $\begin{array}{l}\text { pictures, } \\
\text { charts, } \\
\text { tables }\end{array}$ & $\begin{array}{c}\text { Linear } \\
\text { text }\end{array}$ & $\begin{array}{l}\text { Definition, } \\
\text { conclusion, } \\
\text { sources }\end{array}$ & $\begin{array}{c}\text { The reasons } \\
\text { why } \\
\text { beginners } \\
\text { prefer to use } \\
\text { JavaScript }\end{array}$ & $\begin{array}{l}\text { Black, } \\
\text { blue, } \\
\text { yellow, } \\
\text { white, } \\
\text { grey, and } \\
\text { green } \\
\end{array}$ & $\begin{array}{l}\text { inclusion } \\
\text { of } \\
\text { numbers } \\
\text { (percenta } \\
\text { ge) }\end{array}$ \\
\hline $\begin{array}{l}\text { Modern } \\
\text { language }\end{array}$ & Centre & $\begin{array}{l}\text { chart, } \\
\text { images }\end{array}$ & $\begin{array}{l}\text { Separat } \\
\text { e Linear }\end{array}$ & - & $\begin{array}{c}\text { Which } \\
\text { languages are }\end{array}$ & $\begin{array}{l}\text { Yellow, } \\
\text { blue, }\end{array}$ & $\begin{array}{l}\text { inclusion } \\
\text { of }\end{array}$ \\
\hline
\end{tabular}


The International Journal of Multimedia \& Its Applications (IJMA) Vol.10, No.6, December 2018

\begin{tabular}{|c|c|c|c|c|c|c|c|}
\hline wars & & & $\begin{array}{l}\text { text in } \\
\text { the box }\end{array}$ & & $\begin{array}{l}\text { best for small } \\
\text { business and } \\
\text { job seeker, } \\
\text { and diagrams }\end{array}$ & $\begin{array}{c}\text { green, } \\
\text { black, } \\
\text { white, } \\
\text { red, } \\
\text { orange, } \\
\text { and grey }\end{array}$ & $\begin{array}{c}\text { numbers } \\
\text { (percenta } \\
\text { ge) }\end{array}$ \\
\hline $\begin{array}{lr}5 & \text { reasons } \\
\text { to } & \text { teach } \\
\text { kids } & \text { to } \\
\text { code }\end{array}$ & Right & $\begin{array}{c}\text { Images, } \\
\text { charts }\end{array}$ & $\begin{array}{c}\text { Linear } \\
\text { text } \\
\text { with } \\
\text { image }\end{array}$ & Sources & $\begin{array}{l}\text { Learning } \\
\text { programming } \\
\text { empowers } \\
\text { kids, the need } \\
\text { of } \\
\text { programmers } \\
\text {, and } \\
\text { diagrams }\end{array}$ & $\begin{array}{l}\text { White, } \\
\text { grey, } \\
\text { yellow, } \\
\text { blue, } \\
\text { light } \\
\text { blue, red, } \\
\text { brown, } \\
\text { light } \\
\text { brown } \\
\text { and } \\
\text { black. }\end{array}$ & $\begin{array}{l}\text { inclusion } \\
\text { of } \\
\text { symbols }\end{array}$ \\
\hline $\begin{array}{l}\text { The } \\
\text { history of } \\
\text { programm } \\
\text { ing } \\
\text { languages }\end{array}$ & Right & $\begin{array}{c}\text { Images, } \\
\text { table, } \\
\text { picture }\end{array}$ & $\begin{array}{l}\text { Linear } \\
\text { text in } \\
\text { the } \\
\text { border }\end{array}$ & Introduction & $\begin{array}{c}\text { Early } \\
\text { mechanical } \\
\text { computer } \\
\text { expert who } \\
\text { wrote } \\
\text { algorithm, } \\
\text { and primary } \\
\text { uses of } \\
\text { programming } \\
\text { languages }\end{array}$ & $\begin{array}{l}\text { Black, } \\
\text { white, } \\
\text { blue, } \\
\text { yellow, } \\
\text { red, and } \\
\text { grey. }\end{array}$ & $\begin{array}{l}\text { inclusion } \\
\text { of } \\
\text { symbols } \\
\text { and } \\
\text { subtitle }\end{array}$ \\
\hline $\begin{array}{l}\text { Top } 10 \\
\text { programm } \\
\text { ing } \\
\text { languages } \\
\text { to know in } \\
2014\end{array}$ & Left & Images & $\begin{array}{l}\text { Linear } \\
\text { text and } \\
\text { the } \\
\text { number } \\
\text { in circle }\end{array}$ & Source & $\begin{array}{c}\text { The } \\
\text { description of } \\
\text { programming } \\
\text { languages }\end{array}$ & $\begin{array}{l}\text { White, } \\
\text { yellow, } \\
\text { blue, } \\
\text { orange, } \\
\text { black, } \\
\text { red, grey, } \\
\text { and } \\
\text { brown } \\
\end{array}$ & $\begin{array}{c}\text { The } \\
\text { inclusion } \\
\text { of } \\
\text { symbols } \\
\text { and } \\
\text { subtitle }\end{array}$ \\
\hline
\end{tabular}

Based on Table 3, all 6 programming infographics which were selected included every recommended element from the literature review and experts opinion on a good infographic design.

\section{Conclusion}

There were four different data sources to investigate the elements of infographics in education, which consisted of a literature review taken from 18 references books and journal articles, interview of six experts of design, a content expert's point of view, and the existing design of 6 infographics from the field of education, particularly in programming education. The findings revealed that essential elements include title, graphs/charts/pictures/images, text/font, story, data, color, and design, which should carefully consider the position, portion, types, and appropriateness of each element to make a good infographic design. It can be concluded that this literature review, experts design, and current infographics are all part of a design analysis technique for creating infographics in education. The most important aspect of an infographic 
The International Journal of Multimedia \& Its Applications (IJMA) Vol.10, No.6, December 2018 besides design is content. Based on expert statements for data structure and algorithm content future research could be conducted regarding to infographics about data structure and algorithms.

\section{ACKNOWLEDGEMENTS}

This work is supported by Prof. Madya. Dr. AslinaBintiSaad from University Pendidikan Sultan Idris, Tanjung Malim, Perak, Malaysiaas the advisor and the authors would like to express appreciations to Colleagues who always accompany me to discuss about my research, and University Pendidikan Sultan Idris for their valuable comments and other helps.

\section{REFERENCES}

[1] Lahtinen, E., Ala-Mutka, K., \&Järvinen, H. M., (2005)"A study of the difficulties of novice programmers", AcmSigcse Bulletin, Vol.37, No. 3, pp14-18.

[2 ]Ginat, D., (2004) "On novice loop boundaries and range conceptions", Computer Science Education, Vol.14, No.3, pp165-181.

[3] Seppälä, O., Malmi, L., \&Korhonen, A., (2006) "Observations on student misconceptions-A case study of the Build-Heap Algorithm", Computer Science Education, Vol.16, No.3, pp241-255.

[4] Gomes, A., \& Mendes, A. J., (2007) "Learning to program-difficulties and solutions", International Conference on Engineering Education-ICEE.

[5] Finocchi, I., Grandoni, F., \&Italiano, G. F., (2009) "Optimal resilient sorting and searching in the presence of memory faults", Theoretical Computer Science, Vol. 410, No. 44, pp4457-4470.

[6] Dalton, J., \& Design, W., (2014). A Brief Guide to Producing Compelling Infographics.

[7] Ru, G., \& Ming, Z. Y., (2014) "Infographics applied in design education", Advanced Research and Technology in Industry Applications (WARTIA), 2014 IEEE Workshop on, pp 984-986. IEEE.

[8] Marabella, A. (2014). Communication Theories: An Infographics Development Project (Doctoral dissertation, Southern Utah University).

[9] Zhao, J. Infographics, Communicate Information with Graphics.

[10] Handaru, W. C., Mutiaz, I. R., \&Prihatmanto, A. S., (2015) "Infographics application "Citizen Daily Reporting"-Enabled participatory platform for citizen and government: The case of Bandung cities", Interactive Digital Media (ICIDM), 2015 4th International Conference on, pp1-6. IEEE.

[11] Yani, A. R., Achidatunnisak, I., \& El Chidtian, A. S. C. R., (2015) "Designing infographic book about the risk of free sex for teen girl by using religious approach", International Proceedings of Economics Development and Research, Vol.83, No.21.

[12] Krum, R. (2013). Cool infographics: Effective communication with data visualization and design. John Wiley \& Sons.

[13] Moere, A. V., \& Purchase, H., (2011) "On the role of design in information visualization", Information Visualization, Vol. 10, No.4, pp356-371.

[14] Smiciklas, M. (2012). The power of infographics: Using pictures to communicate and connect with your audiences. Que Publishing.

[15] Lyra, K. T., Isotani, S., Reis, R. C., Marques, L. B., Pedro, L. Z., Jaques, P. A., \&Bitencourt, I. I., (2016) "Infographics or graphics+ text: which material is best for robust learning?", Advanced Learning Technologies (ICALT), 2016 IEEE 16th International Conference on, pp366-370. IEEE.

[16] Albers, M. J., (2014) "Infographics: Horrid chartjunk or Quality communication” ,Professional Communication Conference (IPCC), 2014 IEEE International, pp1-4). IEEE.

[17] Krejčí, M., \&Hradilová, I. (2014). LANDSCAPE INFOGRAPHIC DESIGN. European Scientific Journal, ESJ, 10(10).

[18] Krum, R. (2013). Cool infographics: Effective communication with data visualization and design. John Wiley \& Sons.

[19] Dalton, J., \& Design, W., (2014). A Brief Guide to Producing Compelling Infographics.

[20] Yani, A. R., Achidatunnisak, I., \& El Chidtian, A. S. C. R., (2015) "Designing infographic book about the risk of free sex for teen girl by using religious approach", International Proceedings of Economics Development and Research, Vol.83, No.21. 
The International Journal of Multimedia \& Its Applications (IJMA) Vol.10, No.6, December 2018

[21] Harrison, L., Reinecke, K., \& Chang, R., (2015) "Infographic aesthetics: Designing for the first impression", Proceedings of the 33rd Annual ACM Conference on Human Factors in Computing Systems pp1187-1190, ACM.

[22] Zhao, J. Infographics, Communicate Information with Graphics.

[23] Dalton, J., \& Design, W., (2014). A Brief Guide to Producing Compelling Infographics.

[24] Diakopoulos, N., Kivran-Swaine, F., \&Naaman, M., (2011) "Playable data: characterizing the design space of game-y infographics", Proceedings of the SIGCHI Conference on Human Factors in Computing Systems, pp1717-1726. ACM.

[25] Krum, R. (2013). Cool infographics: Effective communication with data visualization and design. John Wiley \& Sons.

[26] Marabella, A. (2014). Communication Theories: An Infographics Development Project (Doctoral dissertation, Southern Utah University).

[27] Huang, W., \& Tan, C. L., (2007) "A system for understanding imaged infographics and its applications", Proceedings of the 2007 ACM symposium on Document engineering, pp9-18. ACM.

[28] Agwa-Ejon, J. F., \&Batchelor, V., (2016) "The acceptance of infographics for business performance and optimization", Management of Engineering and Technology (PICMET), 2016 Portland International Conference on, pp1847-1858, IEEE.

[29] Yani, A. R., Achidatunnisak, I., \& El Chidtian, A. S. C. R., (2015) "Designing infographic book about the risk of free sex for teen girl by using religious approach", International Proceedings of Economics Development and Research, Vol.83, No.21.

[30] Lee, E. J., \& Kim, Y. W., (2016) "Effects of infographics on news elaboration, acquisition, and evaluation: Prior knowledge and issue involvement as moderators", new media \& society, Vol. 18, No.8, pp1579-1598.

[31-80] Yansyah, Rahmah, Fajrianor, Puspawati, Faizal, Aizzat, Mashitoh., personal communication, 2018. (Personal communication)

\section{AUTHORS}

HusniNaparin gained his Undergraduate Degree (S1) from Department of Technical Information, Technical Faculty, Kalimantan Islamic University, Syekh Muhammad Arsyad Al-Banjary Banjarmasin in 2013 and Graduate Program (S2) from Faculty of Computer Science (Intelligence System), University of Dian Nuswantoro, Semarang, Jawa Tengah in 2015. He is taking Ph.D Program in Faculty of Art, Computing, And Creative Industry, Study program of Artificial Intelligence, UniversitiPendidikan Sultan Idris, Malaysia from 2015-now. His main research interest is Information System, Data Mining, Data Visualization and Multimedia.

Dr. AslinaSaad is working as a Senior Lecturer in Faculty of Art, Computing and Creative Industry. She is a graduate in Bachelor of Information Technology (Science and System Management) and Master of Science (Information Technology). She received her $\mathrm{PhD}$ in Computer Science (Information Systems) from University of Loughborough and is currently attached to UniversitiPendidikan Sultan Idris. Her research interests are on Computer in Education, Management Information System, Artificial Intelligence and Knowledge Management. Currently, she is teaching system analysis and design, Software Design, Software Project, Information System

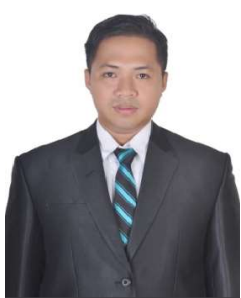

Development and object oriented analysis and design course. 